Original Article

\title{
ANTICONVULSANT EFFECTS OF NIFEDIPINE ON MES INDUCED SEIZURES
}

\author{
JAIN RAINA ${ }^{1}$, JAIN ASHISH ${ }^{2}$, PRASHANT WADAGVALKAR ${ }^{3}$
}

1Department of Pharmacology PCDS and RC Bhopal-India, ${ }^{2}$ Department of Biochemistry PCMS and RC Bhopal-India, ${ }^{3}$ Department of Pharmacology RKDF Medical College, Bhopal-India

Email: jaindrashish@yahoo.co.in

Received: 20 Jan 2018, Revised and Accepted: 08 Mar 2018

\section{ABSTRACT}

Objective: To evaluate the anticonvulsant activity of Nifedipine against MES induced seizures.

Methods: The study was induced by techno electroconvulsometer. The animals were treated with Nifedipine $(100 \mu \mathrm{g} / 100 \mathrm{~g}$ i. p. and $200 \mu \mathrm{g} / 100 \mathrm{~g}$ i. p.) and MES was induced $2 \mathrm{~h}$ after the administration of the drug, and duration of various phases was noted. Duration of THLE was taken as an index for antiepileptic activity.

Results: Nifedipine when administered in a dose of $100 \mu \mathrm{g} / 100 \mathrm{~g}$ ip, did not produce any changes in any phases of the MES induced seizure. But in a dose of $200 \mu \mathrm{g} / 100 \mathrm{~g}$ ip, it significantly reduced the duration of THLE.

Conclusion: Nifedipine has a significant action against MES induced seizures suggesting an important role of CCBs as future, promising antiepileptic drug.

Keywords: Calcium channels, MES seizures, Nifedipine, THLE, Anticonvulsants

(C) 2018 The Authors. Published by Innovare Academic Sciences Pvt Ltd. This is an open access article under the CC BY license (http://creativecommons.org/licenses/by/4.0/)

DOI: http://dx.doi.org/10.22159/ijcpr.2018v10i3.27334

\section{INTRODUCTION}

Epilepsy is one of the most common afflictions of a man with a prevalence of approximately $1 \%$ of the total population. Anticonvulsant drugs act after binding to specific sites within the brain like gamma amino butyric acid, excitatory amino acids and benzodiazepine receptors.

Voltage-gated calcium channels mediate calcium influx that controls both neuronal excitabilities and regulates calcium sensitive intracellular signaling pathways. Previous studies have already shown some alterations in $\mathrm{Ca}_{\mathrm{v}} 3.2$ (gene encoding $\mathrm{T}$ type $\mathrm{ca}^{++}$channels), which may induce altered biophysical properties or increase channel expression [1-4]. The $\mathrm{ca}_{\mathrm{v}} 2.1$ encodes for both $\mathrm{P}$ and $\mathrm{Q}$ type calcium channels and these channels are highly expressed presynaptically where they are critically involved in neurotransmission and synaptic efficacy and therefore have a great influence on neuronal excitability $[5,6]$. Studies have also been carried out on genetic epilepsy-prone rats (GEPRs), and in them induction of secondary tonic-clonic seizure have shown an increase in $\mathrm{ca}_{\mathrm{v}} 1.3$ (L type) and $\mathrm{ca}_{\mathrm{v}} 2.3$ (R type) protein level, in neurons, [7] further supporting the role of calcium ions in epileptogenesis. Thus it may be concluded that calcium current may contribute to epileptogenesis by undergoing burst in pacemaker cells, enhancing postsynaptic excitatory responses in dendrites and somatic nerve cells, and, providing post burst re-excitation. [8] Through intensive research, it has also been highlighted that calcium is also involved in neuronal injury which is caused as a result of repeated seizures. [9] Accumulated evidence shows a clear correlation of calcium channel expression with the development and maintenance of seizures. Thus the present study was undertaken to evaluate the anticonvulsant activity of NIFEDIPINE, which is a dihydropyridine calcium channel blocker, on MES induced seizure.

\section{MATERIALS AND METHODS}

\section{Animals}

Adult, healthy swiss albino mice, aged 6-8 w of either sex weighing 20-30 g were used. They were housed under standard laboratory conditions [controlled temperature (around $22+/-2{ }^{\circ} \mathrm{C}$ ) and humidity $(50 \%)$ colony room] for one week before experiments were started and were kept in groups of 3-4 in per polypropylene cages. Animals were allowed standardized diet and water ad libitum, except for the period of experimentation.
Drugs and chemicals

1. Nifedipine (JB chemicals, Mumbai)-it was dissolved in propylene glycol, just before use.

2. Propylene Glycol (Hi Media, Mumbai)-This solvent was used to dissolve the Nifedipine and it served as solvent control in Nifedipine treated animals.

\section{Method}

The present study was undertaken to see the antiepileptic activity of Nifedipine, which is a DHP calcium channel blocker, against MES induced seizure.

The animals were grouped in three groups, each group comprising of 10 animals.

Maximal electroshock seizure was induced by Techno-electro convulsometer (50 mAmp, 0.1 sec duration) through ear electrodes, via small alligator pinnal clips. Duration of various phases of maximal electroshock seizure (tonic flexion, tonic extension, tonic convulsion, post-tetanic depression) was noted with the help of stopwatch.

In the first phase, the animals were treated with Nifedipine (100 $\mu \mathrm{g} / 100 \mathrm{~g}$ ip). MES was induced by techno-electro convulsometer, $2 \mathrm{~h}$ after the administration of the drug, and various duration were noted.

In the second phase, the animals were treated with Nifedipine (200 $\mu \mathrm{g} / 100 \mathrm{~g}$ ip). MES was induced by techno-electro convulsometer, $2 \mathrm{~h}$ after the administration of the drug, and various duration were noted.

Propylene glycol (0.2 ml/100 g ip) treated animals served as solvent control.

The result were statically analyzed by paired student's' test. P values $<0.05$ were considered significant.

The anticonvulsant effects of Nifedipine were evaluated in the maximal electroshock (MES) seizure test.

\section{OBSERVATION AND RESULTS}

The present study was undertaken to explore the anticonvulsant effect of Nifedipine, a calcium channel blocker, against MES induced seizure. The experimental study was conducted in mice. Each study was conducted with a control group treated with propylene glycol. 
The abolition or reduction of the duration of the tonic extension was considered as an index for antiepileptic activity.

\section{MES seizure test}

When administered in a dose of $100 \mu \mathrm{g} / 100 \mathrm{~g}$ i. p., Nifedipine did not produce any significant change in any phase (tonic flexion, tonic extension, clonic convulsion, postetanic depression) of MES induced seizures ( $>0.05)$. When administered in a dose of $200 \mu \mathrm{g} / 100 \mathrm{~g}$ i. p., Nifedipine significantly reduced the duration of tonic hind limb extension $(\mathrm{p}<0.001)$, but failed to produce any significant change in any other phase of MES induced seizures ( $p>0.05)$.

The tonic hindlimb extensor component was found to be reduced significantly in animals pretreated with Nifedipine. On the basis of these observations, Nifedipine appeared to have a potent antiepileptic effect.

Table: Effect of Nifedipine on the duration of various phases of MES induced seizures

\begin{tabular}{|c|c|c|c|c|c|}
\hline No. & Dose of drug & TF & THL & CC & PTD \\
\hline 1. & Control & $3.3 \pm 0.82$ & $13.9 \pm 1.19$ & $9.0 \pm 0.81$ & $6.0 \pm 0.94$ \\
\hline 2. & $\mathrm{~N}(100 \mu \mathrm{g} / 100 \mathrm{~g})$ & $3.1 \pm 1.01$ & $13.7 \pm 1.03$ & $8.9 \pm 1.02$ & $5.6 \pm 1.05$ \\
\hline 3. & $\mathrm{~N}(200 \mu \mathrm{g} / 100 \mathrm{~g})$ & $3.2 \pm 0.99$ & $4.7 \pm 0.76$ & $8.8 \pm 1.02$ & $5.8 \pm 1.03$ \\
\hline
\end{tabular}

$\mathrm{N}=$ Nifedipine, $\mathrm{TF}=$ tonic flexon, $\mathrm{THLE}=$ tonic flexon leg extension, $\mathrm{CC}=$ clonic convulsion, PTD = post tetanic depression, Values are given as mean \pm SEM $(n=10)$.

\section{DISCUSSION}

The current experimental study has been planned with an objective to study the antiepileptic effects of Nifedipine on MES induced seizures. From the experimental results, it was found that Nifedipine do have a significant anticonvulsant action. This anticonvulsant action may be based on the facts that, during the episode of epileptic attack there is ischemia and excitation which can cause damage in the hippocampus and cerebellar cortex [10]. Epileptic depolarization in single motor and hippocampal neurons and focal epileptic discharges in neuronal cortical preparations have also been described to be decreased by calcium channel blockers and hence CCBs prevents cell damage [11]. The anticonvulsant effect of Nifedipine may also be correlated with the increase in local blood flow due to vasodilatation [12], and all these effects of Nifedipine may be due to central blockade of calcium entry through dihydropyridine L-type calcium channels [13]. It has been established that even small alterations in the biophysical properties of presynaptic calcium channels could have a significant impact on the firing properties of nerve cells and neuronal networks with the potential to lead to epileptic seizure activity [14-16]. The fact that CCBs do not directly inhibit neurotransmitter release, except, in the situation of ischemia and excitation, can encourage the use of these drugs as non-sedative anticonvulsants without the risk of a catastrophic effect on neurotransmission [17]. The considerable effect is still going on towards developing new and selective calcium channel blocking compounds aimed at the treatment of epilepsy [18]. In conclusion, as we already know that many of the currently used antiepileptic drugs have been shown to block the calcium channels and the present study also demonstrated that Nifedipine (calcium channel blocker) has anticonvulsant action, calcium channels are more commonly viewed as attractive targets for novel epileptic therapies.

\section{AUTHORS CONTRIBUTIONS}

All the author have contributed equally

\section{CONFLICT OF INTERESTS}

\section{Declared none}

\section{REFERENCES}

1. Singh B, Monteil A, Bidaud I, Sugimoto Y, Suzuki T, Hamano S, et al. Mutational analysis of CACNA1G in idiopathic generalized epilepsy. Hum Mutat 2007;28:524-5.

2. Chen Y, Lu J, Zhang Y, Wu H, Liu X, Jiang Y, et al. Association between genetic variation of CACNA1H and childhood absence epilepsy. Ann Neurol 2003;54:239-43.

3. Heron SE, Khosravani H, Varela D, Bladen C, Williams TC, Newman MR, et al. Extended spectrum of idiopathic generalized epilepsies associated with CACNA1H functional variants. Ann Neurol 2007;62:560-8.

4. Liang J, Zhang Y, Chen Y, Wang J, Pan $\mathrm{H}, \mathrm{Wu} \mathrm{H}$, et al. Common polymorphisms in the CACNA1H gene associated with childhood absence seizure in Chinese Han population. Ann Hum Genet 2007;71:325-35.

5. Bourinet E, Soong TW, Sutton K, Slaymaker S, Mathews S, Monteil A, et al. Splicing of alpha 1A subunit gene generates phenotypic variants of P-and Q-type calcium channels. Nat Neurosci 1999;2:407-15.

6. Trimmer JS, Rhodes KJ. Localization of voltage-gated ion channels in mammalian brain. Annu Rev Physiol 2004;66:477519.

7. N Gouemo P, Yasuda R, Faingold CL. Seizure susceptibility is associated with altered protein expression of voltage-gated calcium channels subunits in inferior colliculus neurons of the genetically epilepsy-prone rat. Brain Res 2010;1308:153-7.

8. Heinemann IJ, Hamon B. Calcium and epileptogenesis. Exp Brain Res 1986;65:1-10.

9. Grifffths T, Evans MC, Meldrum BS. Intracellular sites of early calcium accumulation in the rat hippocampus during status epilepticus. Neurosc Lett 1982;30:329-34.

10. John H Menker, Raman Sarkar. Paroxysmal disorders. Text Book of childhood neurology. $5^{\text {th }}$ edition; 1995. p. 724-60.

11. Speckmann EJ, Walden J, Bingmann D, Specific suppression of pentylenetetrazol-induced epileptiform discharges in CA3 neurons (hippocampal slice, guinea pig) by the organic calcium antagonists flunarizine and verapamil. Exp Brain Res 1989;39:149.

12. Desai CK, Dikshit RK, Mansuri SM, Shah UH. Comparative evaluation of anticonvulsant activity of CCBs in experimental animals. Indian J Exp Biol 1995;33:931-4.

13. Meyer FB, Anderson RE, Sundt TM. Anticonvulsant effects of dihydropyridine calcium antagonists in electrocortical shock seizures. Epilepsia 1990;31:68-74.

14. Catterall WA. Structure and function of neuronal calcium channels and their role in neurotransmitter release. Cell Calcium 1998;24:307-23.

15. Neher E, Sakaba T. Multiple roles of calcium ions in the regulation of neurotransmitter release. Neuron 2008;59:86172 .

16. Wadel K, Neher E, Sabaka T. The coupling between synaptic vescicles and calcium channels determines fast neurotransmitter release. Neuron 2007;53:563-75.

17. Spedding M. Trends Pharmacol Sci; 1987. p. 115.

18. Tringham E, Powell KL, Cain SM, Kuplast K, Mezeyova J, Weerapura $\mathrm{M}$, et al. T type calcium channel blockers that attenuate thalamic burst firing and suppress absence seizures. Sci Transl Med 2012;4:12-9. 